\title{
IT'S THE SAME THE WHOLE WORLD OVER: BRIDGING THE GAP IN NEW ZEALAND
}

\author{
Elizabeth Probert \\ Teacher-librarian \\ Pakuranga College \\ Pigeon Mountain Road \\ Bucklands Beach, Aukland \\ New Zealand \\ E-mail: eprobert@iconz.co.nz \\ John Fowler \\ Teacher-librarian \\ King's College \\ Mangere, Aukland \\ New Zealand
}

\begin{abstract}
Since 1990, education in New Zealand has undergone dramatic changes. A new K-12 framework has been put in place with the curriculum divided into Essential Learning Areas and Essential Skills Areas. For the first time all students are required to develop information skills yet New Zealand has never had a tradition of full time teacher-librarians. There is now a diploma course for teacher-librarianship but most high school teacher-librarians have only five hours per week in the library. Primary teachers usually have no release time. This paper aims to show how New Zealand teachers and school libraries are facing the challenge and attempting to "Bridge the Gap."
\end{abstract}

\section{HISTORY OF EDUCATION IN NEW ZEALAND}

For teacher-librarians in many parts of the world these are challenging and fast-changing times. Many education systems are having to come to grips with new or revamped curricula, assessment methods are changing, the role of the teacher is changing as learning styles change and the need for Total Quality Management is ever present. There are also funding problems, management restructuring, parents who expect more than ever from the schools, and students who know their rights.

Things are no different in New Zealand. From the 1830s on, European settlers in New Zealand were quick to build schools. The 1877 Education Act laid down that all children should attend primary school. Secondary schools (although there were some, based on English public schools), were not seen as important, and only about ten per cent of children leaving primary school continued on to secondary school. By 1900 there were fourteen high schools throughout New Zealand, but students had to pass a proficiency examination to enter them and even by 1930 only 55 percent of those completing primary school were going on to secondary education. It was not until 1936 when the proficiency exam was abolished that all New Zealand children could enter secondary education, and by 194070 percent did so. In 1944 there were more changes when the age for compulsory school attendance was raised to fifteen, a core curriculum was introduced, and the University Entrance examination could be accredited to students who had reached a high enough standard throughout the year. In 1946 the School Certificate examination was introduced.

\section{Tomorrow's Schools and More Changes}

The next significant change in the New Zealand education system started in 1988 with the publication of Tomorrow's Schools: The Reform of Education Administration in New Zealand which, 
as stated in the Introduction "...outlines the most thoroughgoing changes to the administration of education in our history...[and] is a statement of the Government's intent." (p. 1) Among these farreaching reforms were:

- Each school controls of its own educational resources and uses them as it sees fit (within general guidelines set by the state);

- Each school is run by an elected Board of Trustees which appoints the principal and approves other appointments of teaching staff and non-academic support staff on the recommendation of the principal;

- Each school receives a bulk grant to fund all school activities except teachers' pay. (Some schools however are taking part in a trial whereby teachers' pay is also bulkfunded and can be distributed as the Board of Trustees and principal decide fit).

The New Zealand Curriculum Framework, after several drafts, was published in 1993 and sets out the foundation policy for learning and assessment in schools. It identifies seven Essential Learning Areas and eight Essential Skills Areas: "In planning learning programs, schools need to ensure that all students have the opportunity to develop the full range of the essential skills to the best of their ability...[The essential skills] will be developed through the essential learning areas and in different contexts across the curriculum." (p. 17) (see the figure on the following page)

\section{The Significance of These Changes}

The contents of this new Curriculum Framework document have enormous implications for education in New Zealand. Not only are schools being organized and managed in different ways but there are and will be vast changes in the ways teachers teach and students learn.

It is the Essential Skills Area that provides the greatest challenges to the New Zealand teacherlibrarian or teacher with library responsibility (TLR). Almost 76 percent of the listed skills are actually information skills. Therefore, if a school has an active program of developing information skills across the curriculum which is led and facilitated by the teacher-librarian or TLR, then most of the essential skills (apart from some physical, numeracy and social skills) will be covered. It is significant however that the development of information skills is being monitored by the National Monitoring Program. All the other groups of essential skills are to be developed within curriculum areas, but information skills alone are seen as being important enough to warrant this monitoring across the curriculum. To implement the Essential Skills Area of the new curriculum, therefore, schools need to have trained teacher-librarians and teachers trained in teaching information skills.

\section{BACKGROUND TO TEACHER-LIBRARIAN TRAINING IN NEW ZEALAND}

Until the advent of Tomorrow's Schools 1988 secondary school libraries were administered by a teacher appointed as the TLR. The job was often given to a teacher in the English Department and was not an advertised position. The teacher appointed had no training in managing school libraries, but the position gave the TLR a time allowance of five hours per week for library matters. Since Tomorrow's Schools the five hour time allowance is no longer guaranteed. Principals have discretion to give whatever library release time they feel is sufficient and many TLRs have found their five hours have dwindled to only two or three. Others, especially those who have undertaken teacherlibrarianship training as described below, have been able to demonstrate the necessity for, and value of, having more release hours for library and information skills implementation.

Primary school TLRs rarely have any release time for school library management, although there are schools where many staff members have undergone training in teaching information skills.

\section{Teacher Librarian Training}

In March 1986 a group of twenty teachers gathered at Wellington Teachers College to begin the first one-year post-graduate diploma course in Teacher-Librarianship. This educational initiative was 
The New Zealand Curriculum Framework Te Anga Marautanga o Aotearoa

All young people in New Zealand have the right to gain, through the state schooling system, a broad balanced education that prepares them for effective participatin in society

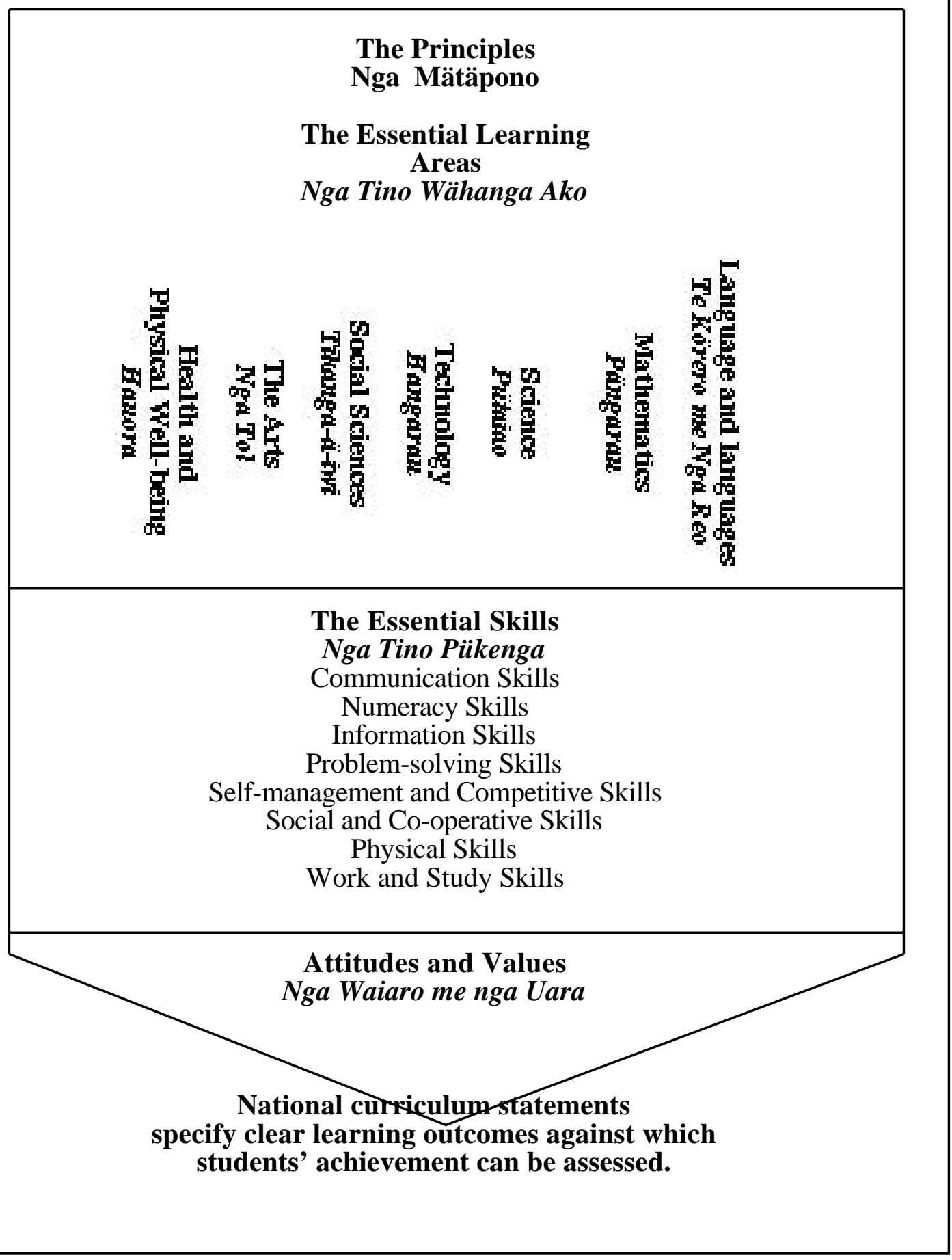


instigated by The Minister of Education, the Hon. Russell Marshall, a minister of considerable foresight but unfortunately brief tenure.

The course was devised and directed by Gwen Gawith, who had returned to New Zealand to take up this post from training teacher-librarians in Perth, Australia. The structure of the course was innovative: it involved experienced teachers from all grade levels, junior, middle and senior, and from a broad range of rural and urban schools. It consisted of a number of modules and was an experience-based, hands-on course. Each teacher had class-release for this study year, but remained attached to a base school, spending up to two days per week managing the school library and completing the necessary practical, class-based teaching components of the program. The remainder of the week was spent as a full-time student completing assignment work, undertaking research and preparing materials for the course. In 1986 the school year was organized into three terms of thirteen or fourteen weeks (it has now moved to four terms of ten weeks each). Four weeks of each term were spent with the group together at the newly-established School of teacher-librarianship at Wellington Teachers College, where the underlying philosophical and pedagogical basis for teacher-librarianship and the skills required for it were closely focused upon and there was an opportunity for the sharing of work and experience from the school-based components of the program. In this way the course provided a balance of practical learning and experience in library management, for the honing of skills to promote and develop resource-based learning programs across the curriculum, and individual learning for all those involved.

After the one-year training period the teachers returned to their full-time, permanent positions as Trained Teacher-Librarians. A second group of twenty teachers entered training in 1987 and a third in 1988. However, because of government educational funding cuts at that time, the course was curtailed, and the long-term tenure of the Trained Teacher-Librarian positions was put in doubt. (These full-time positions were maintained until 1994, when it became the prerogative of the individual schools as to whether these positions continued, so long as they fitted within the existing staffing ratios). There was no further national staffing provision made for teacher-librarians and it is not surprising that few positions were maintained.

What a cruel blow for such a forward-looking and valuable adjunct to the teaching and learning processes in our schools! This was especially so because of the positive evaluation in a threeyear study undertaken by Geoff Lealand for the New Zealand Council for Educational Research which concluded "...this innovation has been both successful and effective" (Lealand, 1990, p. 89) and spoke of it as having:

encouraged a wider and more diverse use of resources, introduced different perspectives on teaching and learning, and perhaps most importantly, promoted selfesteem amongst considerable numbers of students, who are now realizing that the acquisition of knowledge through resource-based learning can be both a pleasurable and powerful process. (p. 90)

However, as far as teacher-librarianship training went, all was not lost. The course director, Gwen Gawith, was appointed to redefine the scope and manner of future teacher-librarian training, with the brief to set up a three-year part-time course equivalent to the previous one-year full-time postgraduate diploma. Unfortunately, as there were no specific jobs available for newly-trained Teacherlibrarians, the incentive to train as specialists was not great! Yet the inclusion of information skills in the Essential Skills Area of The New Zealand Curriculum Framework (1993) provided a means of continuing the growing focus on resource-based learning, and, in fact, a real incentive for teachers to pursue information studies as a means of improving their teaching skills to facilitate the learning of their students.

In 1990 Gwen Gawith was appointed as National Coordinator of the Department of Information Studies and Teacher-librarianship which was based at Auckland College of Education and it was the flexibility of the courses she developed which was to be the key to future success. The Information Studies program, which began in 1991, consists of three related specialist diplomas for trained teachers: the Diploma of Information Studies: the Diploma of Teacher-librarianship: and the Diploma of Information Technology. All of these diplomas have the same core papers, but offer different avenues for specialization. Teachers can choose to do only one or only two papers, or to complete the full diploma over three or four years of part-time study. 
The courses offered are all based on distance-learning methods. Centrally coordinated from Auckland, they are offered nationally through the six colleges of education and at several other offcampus sites which may be individual schools. Each site has its own tutor(s) for the sessions (initially from the group of teacher-librarians trained between 1986 and 1988, but more recently they have been assisted by others who have graduated through the part-time course). Sessions run simultaneously at each site and following each two-hour workshop, the centers link for an hour-long teleconference to share feedback and prepare for the next week's school-based practice.

The courses, which run over ten weeks of a school term with a Friday evening -Saturday workshop included, have been enormously successful. They have drawn junior, middle and senior school teachers and the consequent sharing of learning across the levels is unique in New Zealand teacher training and experience.

The base module for all three diplomas is Infolink, a six stage framework of information skills, which Gwen Gawith has developed from the British research of Ann Irving, who was among the first to encourage the development of information skills programs which are totally integrated with classroom-based curriculum work. Later, Michael Marland developed a nine step information model with the stages of the information process expressed as questions. Gwen Gawith adapted this to a six-stage model which has been integrated into her programs since 1987.

The modular distance-learning format is supported with study guides, workbooks and audio and video tapes, as well as with substantial audio conferencing to encourage teachers from all over New Zealand to share their classroom-based experiences as an integral part of the learning. Each stage is workshopped in core sessions with the teachers who then implement this learning with their own classes prior to the next session. Through this experiential resource-based model of learning, teachers are provided with first-hand knowledge of how the process of resource-based learning will operate for their own pupils.

Currently, over 600 teachers per year undertake the basic Infolink paper of the Information Studies program. In this way the critical mass of teachers who understand and use the process of resource-based learning is growing. The number of teachers who have gone on to complete the Diploma in Teacher-librarianship is minimal in relation to the total, but since 1991 over two hundred have done so-all the more amazing, considering that specialist jobs are no longer likely to be available. Many teachers are making a niche within their own schools as it is realized how effective they can be in improving the quality of student learning. A number have won the support of their principals and have been given class-release time to manage the library and to promote the concept of resource-based learning in cooperative programs across the curriculum. This is in effect teacherlibrarianship —although not full-time and not fully recognized-in these particular schools.

The Ministry of Education has not seen fit to support the efforts of concerned schools and boards, or of individual teachers, in best providing for the delivery of the information skills written into The New Zealand Curriculum Framework. The teacher training is available to enable New Zealand teachers to handle superbly well the impact of the information age on education. It appears short-sighted not to take full advantage of a program which, by its very nature, offers accessibility throughout the country to trained, experienced teachers with the professional commitment to participate.

\section{The National Library School Library Development Focus Program}

A different type of assistance to schools is offered by the National Library School Library Development Focus Program. This program was conducted on a trial basis in 1995. In 1996165 schools throughout New Zealand joined in with even more applicants for the 1997 slots.

The Focus Program involves a team of staff, with representatives (often heads) from most departments in a secondary school, who work with a Library Adviser/Facilitator over the year to develop a three to five-year school library development plan. The future of the library, therefore, becomes a whole-school activity with everyone able to have input. Teachers can look at the way learning and teaching styles may change once the new curriculum statements are fully implemented and can plan accordingly. The place the Library/Information Resource Centre will play in a particular school, and the ways in which information will be managed, accessed and used to support the school's learning programs, are fully discussed.

As well as helping with the planning, the adviser concerned assists with policy development, arranges visits to other libraries so that staff can see how, for example, information technology can be 
used, and helps staff to look at the planned development of information skills in their schools. Very often members of a school staff, and in some cases the whole staff, will enroll in Auckland College of Education's Department of Information Studies Infolink course.

This National Library initiative has been extremely successful. At a recent meeting several principals were heard praising the Focus Programmme and detailing how invaluable it had been in helping them link their planning for the learning programs of their schools to the planned refurbishing or rebuilding of their school libraries.

One very important advantage, of course, is that taking part in the Focus Programme ensures a central and high profile role for a school library. It also means that staff are able to take a long look at how they want their students to learn in the future and at how they are going to provide for any expected changes. The whole school gets involved, with the library development right at the center where it should be.

\section{PERSONAL EXPERIENCES IN BRIDGING THE GAP}

\section{John Fowler, Teacher-Librarian, King's College}

King's College is a private Anglican boarding and day school in Auckland, New Zealand. Established in 1886, it celebrated its centenary last year, and is one of New Zealand's oldest and most prestigious schools. It has 869 pupils from Year 8 to 13 , with approximately half being boarding students and half day students. Although known as a boys' school King's was the first school of its type, 18 years ago, to have the good sense to admit girls to its senior levels 12 and 13. There are currently 102 girls on the roll. The school population is mainly of European extraction with only six percent from other nationalities. In its aspirations, King's looks to the great English public schools and aims to foster the best of traditional education-academic, sporting and cultural — while taking full advantage of modern educational developments. King's College is at the forefront of New Zealand schools in its integration of information technology into the curriculum, and it is a feature of the college that it has an open-door policy of welcoming visitors and of sharing its educational knowledge and expertise.

\section{Information Technology at King's College}

A King's College trial of the use of computers (both laptop and desktop machines) in several junior classes between 1991 and 1993 was favorably assessed by an independent researcher in 1994. In 1992, as part of this trial, all teaching staff were issued with Apple Powerbook 100s. Although the college retained ownership of these computers, having their "own" computer made a significant contribution to staff professional development and training in the use of computers, which were upgraded to Apple 520c machines in 1996. In 1994 the college campus was networked throughout (all classrooms, offices and boarding houses) with fiber-optic cabling from the new Library and Information Centre, and preparation of a five-year Information Technology Plan was undertaken with an outside consultant. This plan recommended the continued use of the Apple platform and the introduction of compulsory laptop computers for all Year 12 students from 1996 (the Powerbook 150 or 190). In 1997, the second year of this laptop project, there are 400+ students carrying laptops to classes daily. The main software used is ClarisWorks for word processing, spreadsheets and databases, but each department has also developed a range of subject-specific software. Full e-mail communication is available to all staff, and a growing number of students, and the school has an ISDN line to access the Internet - available to all staff via their laptops, and to students via the Library Internet computers and the computer room. The college is currently employing a consultant to assist in preparing its IT 2000 plan. A Network Manager is employed to maintain the network and two computer technicians repair computers under warranty in the Service Centre. Teacher training in the use of computers was initially provided by the Heads of Department, Computing, or by short external courses, but increasingly the seven Technology Coaches (teachers appointed to the various subject departments to assist them with their use of computers and IT) provide the necessary short training sessions or one-on-one coaching to raise the level of expertise. Subject teachers are thus enabled to train their students in the use of subject-specific information technology. 


\section{The Teacher-Librarian at King's College}

With the development of the new Library and Information Centre at King's College, I was appointed in 1994 as teacher-librarian to manage the library and develop the concept of resourcebased learning across the curriculum. I am one of the 1986-trained group of teacher-librarians at and had, since 1987, worked full-time in that role at Long Bay College, a co-educational state school. In my new position as teacher-librarian at King's College I was also responsible for teaching English to two classes. In retrospect, I see this as a positive factor in quickly earning acceptance by both teaching colleagues and students.

To be most effective as teacher-librarian it is vital to have the ear of colleagues in order to know at first hand of any changes in curriculum or methods of assessment-and these are certainly happening in New Zealand! My teaching commitments, however, mean that I am not available to teach in information skills programs in all option lines. There are inevitably some gaps, though over a number of subjects I do get to see all students. I help subject departments plan programs, including research-based work, which will enable the development of the students' information literacy. I see this as a vital consciousness-raising need, all the more so as King's College, prior to 1994, worked students very much in the traditional academic mode. It has therefore been heartening to find enthusiastic support from the college's teachers for enquiry-based learning.

One of the most pressing needs at first was to develop the library as a base for successful resource-based learning. A greater number and much wider range of curriculum-related resources was required with a broader range of reading levels (often the content of library resources was inaccessible to less able students). Our automated catalogue system was networked for staff and student access. An Information File was built up for local and current material. Access was provided to a wide range of CD-ROMs disks through the computer network. Up-to-date encyclopedias were purchased. A document supply service for New Zealand material (Index New Zealand) was subscribed to. Last year we began to provide student access to the Internet for curriculum-related searching. There are now five computers online all day in the library. King's College students have access to a wealth of information-theirs is an information-rich environment.

What is required now are the skills to help turn that information into knowledge. My current (and continuing) emphasis is to focus on the pre-assignment work; to concentrate on the "Deciding" stage of the information process, keeping students away from the resources until they know precisely what they want and need to find out. No matter what their final work is to be students must have a clear understanding of what they need to know-what they need to find out. I have found that class time spent working through this step is essential to the success of the learning. It takes time, but is time well spent.

Even when the presentation format is an academic-style essay, it is beneficial to define the topic in terms of questions which need answers (Why? How? What?). This helps provide a paragraph structure for the essay and, more significantly, helps students keep out irrelevant material which could weaken their presentation. Most of all it helps them to be confident that they are dealing with the topic in an appropriate manner.

King's College students are generally highly computer-literate. They have a wide range of information access options available to them and many are adept at the cut and paste routine, using photocopied notes and CD-ROM and Internet printouts. Increasingly, teachers consider this approach inadequate and are keen to structure assignments to force genuine research and meaningful synthesis of information. The mentality which says "just hand it all in, and let the teacher sort it out," is no longer acceptable and the student has to work harder, but with a greater possibility of real success and ensuing satisfaction.

I would like to see the development of greater confidence by students in their own notemaking skills, so that they know they can make sense of information. I would also like to focus more closely on the effective evaluation of independent enquiry-based learning, by the students themselves, their peers and their teachers. This can only foster a clearer awareness of how information serves the needs of the user-can only serve to bridge the gap between the information 'out there' and the requirements of the individual. 


\section{PERSONAL EXPERIENCES IN BRIDGING THE GAP}

\section{Elizabeth Probert, Teacher-Librarian, Pakuranga College}

Pakuranga College is a large state co-educational high school in Auckland with almost 1800 students (ages 13 to 18) this year, up from 1630 in 1996. Students wishing to attend must live within the school zone although over the past couple of years we have taken in a small number of feepaying students. We have 43 different nationalities represented among our students, 48 percent of whom were not born in New Zealand but come mainly from Taiwan, Hong Kong, Korea and Iraq.

\section{The Teacher-Librarian at Pakuranga College}

When I first became TLR I had the usual five hours of release time. During my second year in the job I embarked on the three year Diploma of Teacher-librarianship and quickly began to see that there was no way I could introduce school-wide, across-the-curriculum information skills development on five hours a week. I explained to my very supportive principal what I would like to achieve and the following year I was allotted more hours out of the class room. I was also allotted management units. At the end of last year, after reading a report on how my time was spent and what had been achieved in the library, the principal suggested that perhaps in 1997 I needed to be full time.

However, after much consideration, I have come to the conclusion that there are big advantages in having some time in the classroom. I have noticed that teachers who don't teach often lose credibility with the rest of the staff and can lose touch with the students. I have two English classes and a Year 10 Life Skills class twice a week. Teaching these classes keeps me in touch with curriculum problems, new methods of assessment, and current student thinking. I am part of the staff and not someone seen as having a non-teaching job. As the school runs a House system with vertical grouping I also have a Tutor Group and with it, another opportunity to interact with students.

My teaching load means that I have to plan my teacher-librarian activities very carefully. I have two excellent library staff members, working with me and together we look at the long term and short term goals we set for last year and decide on goals for the coming year. These goals, of course, are founded on the vision statement we wrote for the library when we were a trial school for the National Library Focus Programme and on our Library Policy document.

I was concerned this year when reviewing our goals for 1996 to note how many of them were to do with finding information - that is with helping students know where to look -in which part of a book or periodical, how to search a CD-ROM database and the Internet, or with the training of student librarians to help with library management in order that information can be found.

However, the more I work with students and teachers the more I realize that one of the keys to bridging the gap lies with helping students develop the skills needed to use all the information they can now find as well as helping them with the "deciding" and the "finding" stages of the process.

There are many skills involved in using information-skimming and scanning pages, the ability to take notes without rewriting the whole chapter, combining notes from various sources, evaluating both information and sources, synthesizing the information so that it is turned into knowledge, realizing when a question has been answered.

\section{Main 1997 Goal}

I therefore decided that this year I would target a specific skill in the "using" stage-notetaking. I chose this particular skill as many teachers feel their students are not able to take notes efficiently. However I also wanted to demonstrate that someone, the teacher-librarian, needs to plan to introduce the skill in all subject areas. I hoped to show that the planned cross-curricular development of a certain skill can lead to all students learning, for example, to take notes in a more efficient way which will benefit them in all classes and all subject areas.

I designed a short (four periods) pre-teaching unit (Fig 2) to precede my Year 10 English class's individual English research assignments. All English classes undertake research assignments, with each year's assignment requirements building on the requirements of the previous year. The Form 3 assignment is a show-and-tell presentation. Year 10 students research leisure and present their findings in chart form while Year 11 students write a report (not an essay) on a New Zealand topic and Form 6 students research and present a report (again not an essay) on a language topic. 
In the trial pre-teaching unit, students skipped the deciding and finding stages as I provided the questions and the material with which to answer them. In groups, students skimmed, scanned, and took notes, using the "Dot-Jot" method. They then combined these notes, did some thinking and came up with answers to their three questions.

\section{Note Taking}

The class learned to take notes using the Dot-Jot ( sometimes called bullet point or dash-jot notes) This is an excellent method of notetaking-put a dash or a dot then jot down a point. Students often think note taking is simply rewording the original. It is very hard to get them to see it is acceptable not to have complete sentences.

Each question is written at the top of a fresh sheet of paper. Notes are jotted down on the left hand side and the sources of the notes are written down the right side. (Fig 3)

\section{Progress So Far}

I have been really pleased with this unit and at the ease with which students changed the way they took notes. I have also noticed that they seem to have found it easier to combine the notes from various sources in order to answer the questions.

Other teachers who have now taken classes through the procedure are also pleased at the progress their students have made. I have now discussed the procedures with the head of another large department who was delighted to become involved after I showed her what some of her students were starting to accomplish in English classes. I can see that despite the size and complexity of the school we should, with careful planning, be able to have all Year 10 students using this type of note taking.

These, then, are some of ways we are trying to bridge the gap at Pakuranga College. However, I think it is important to realize that:

- developing the skills needed to become information literate takes a long, long time, perhaps many years;

- certain skills need to be targeted for specific practice;

- that such skills will not be developed across the curriculum and throughout all levels unless someone has decided that this will happen and makes plans accordingly.

Then, as the saying goes, "It won't happen overnight but it will happen." 


\section{Research \\ into \\ L eisure}

Y ou are doing this unit as background to your individual research where you will investigate a leisure activity of your choice.

By the end of this unit you should have:

- a definition of leisure

- an understanding of the history of leisure

- and understanding of how and why your lives might be different from the lives of other 14 year olds, past or present.

This unit will also give you practice in U S I N G information, i. e. skimming and scanning printed material, note taking, combining notes from various sources, thinking out your answers, coming to conclusions and presenting them orally to the class.

Y ou will be working in groups of three or four students and will answer three questions: numbers one and two and one other.

1. What is leisure?

2. How would your life be different if you were living in B ritain in the 19 th C entury as part of a poor family?

3. We tend to take the 40 hour week for granted - has it always been in place? I f not, why not, and what changes occurred over time?

4. What is child labour and how extensive was it last century? Give examples of common working conditions for children.

5. How extensive and why is child labour today and how could conditions be improved?

Y ou group will present their findings on (date)

\footnotetext{
Each group is provided with a folder of material form 14 sources which includes information such as

- Ashley's Mines Commission testimony (1842)

(http://www.stg.brown.edu/projects/hypertext/landow/Victorian/history/workers2.html)

- history of the eight hour day in New Zealand

- material on child labour from various encyclopaedias (print and electronic)

- accounts of child labour (http://www. earlham.edw/www/polisci/globalprobs/Janet.html)
}

Figure 2. Research Assignment: Focus on USING information - note taking techniques. 
How would my life be different if I was living in Britain in the 19th century and came from a poor family?

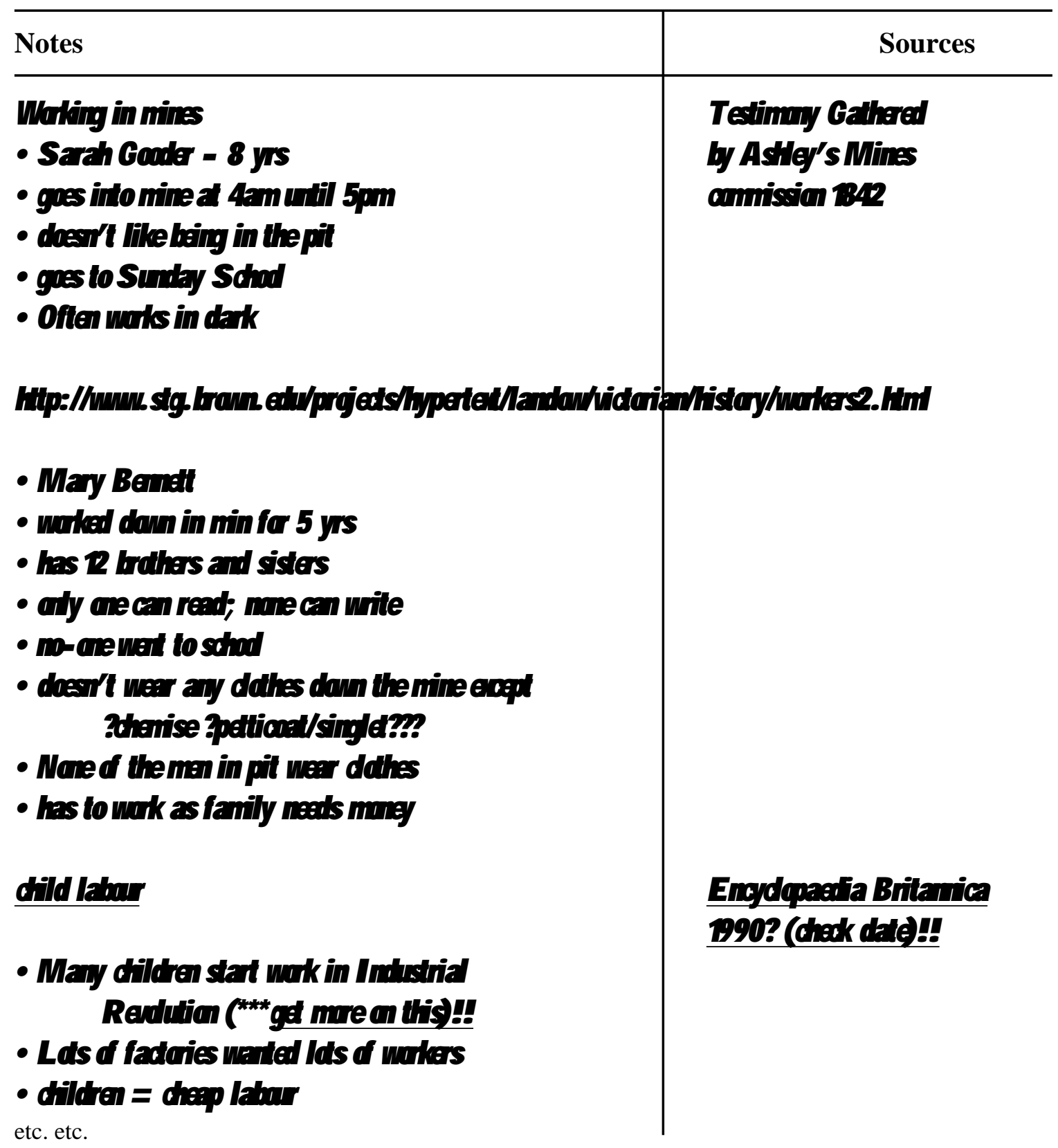

Figure 3. Example of student note-taking 


\section{CONCLUSION}

This has been brief picture of how New Zealand schools are trying to bridge the gap. While many schools have yet to come to grips with the requirements of the Essential Skills Area of our new curriculum, others have already had whole staff training in the teaching of information skills.

It is this development from the ground up that is so exciting and so unusual. While the Ministry of Education put the new curriculum in place, it is teachers, realizing the need for change, who are driving its implementation, especially of the Essential Skills Area. Such activities are indeed helping to lay very strong foundations on which to build these changes in teaching and learning and more and more teachers are able to see the important part that the trained teacher-librarian can play in this process.

School libraries and trained teacher-librarians in New Zealand are destined to play a vitally important and increasingly central role in the education of all students in years to come.

\section{NOTES}

* In New Zealand students start school in Year 1 at the age of 5 years. Consequently the final year of high school is Year 13.

\section{REFERENCES}

Gawith, G. (1987). Information alive: Information skills for research and reading. Auckland: Longman Paul.

Irving, A. \& Snape, W. (1979). Educating library users in schools (Rep. No. 5467). London: British Library Research \& Development Department.

Lealand, G. (1990). The educational impact of the appointment of full-time Trained Teacher-Librarians (Final report). Wellington: New Zealand Council for Educational Research.

Marland, M. (1981). (Ed.). Information skills in the secondary curriculum. London: Methuen Educational.

New Zealand Curriculum Framework. (1993). Wellington: Ministry of Education.

Tomorrow's Schools. (1988). Wellington: Ministry of Education. 